\title{
No Time to Waste: Real-World Repurposing of Generic Drugs as a Multifaceted Strategy Against COVID-19
}

Moshe Rogosnitzky ${ }^{1}$; Esther Berkowitz ${ }^{1}$, MBChB, MA; Alejandro R Jadad ${ }^{2}$, MD, DPhil, FRCPC, FCAHS, FRSA, LLD

${ }^{1}$ Medinsight Research Institute, Rehovot, Israel

${ }^{2}$ Program in Impactful Giving, Dalla Lana School of Public Health, University of Toronto, Toronto, ON, Canada

Corresponding Author:

Moshe Rogosnitzky

Medinsight Research Institute

Pekeris 4

Weizmann Science Park

Rehovot, 7670204

Israel

Phone: 972522945520

Email: moshe@medinsight.org

\section{Related Articles:}

Preprint: https://preprints.jmir.org/preprint/19583

Peer-Review Report by Ahmed Abdeen Hamed (Reviewer E) https://med.jmirx.org/2020/1/e24453/

Peer-Review Report by Susan Howlett (Reviewer F) https://med.jmirx.org/2020/1/e24481/

Author Responses to Peer-Review Reports https://med.jmirx.org/2020/1/e24485/

\begin{abstract}
Real-world drug repurposing — the immediate "off-label" prescribing of drugs to address urgent clinical needs—is an indispensable strategy gaining rapid traction in the current COVID-19 crisis. Although off-label prescribing (ie, for a nonapproved indication) is legal in most countries, it tends to shift the burden of liability and cost to physicians and patients, respectively. Nevertheless, in urgent public health crises, it is often the only realistic source of a meaningful potential solution. To be considered for real-world repurposing, drug candidates should ideally have a track record of safety, affordability, and wide accessibility. Although thousands of such drugs are already available, the absence of a central repository of off-label uses presents a barrier to the immediate identification and selection of the safest, potentially useful interventions. Using the current COVID-19 pandemic as an example, we provide a glimpse at the extensive literature that supports the rationale behind six generic drugs, in four classes, all of which are affordable, supported by decades of safety data, and pleiotropically target the underlying pathophysiology that makes COVID-19 so dangerous. Having previously fast-tracked this paper to publication in summary form, we now expand on why cimetidine/famotidine (histamine type-2 receptor antagonists), dipyridamole (antiplatelet agent), fenofibrate/bezafibrate (cholesterol/triglyceride-lowering agents), and sildenafil (phosphodiesterase-5 inhibitor) are worth considering for patients with COVID-19 based on their antiviral, anti-inflammatory, renoprotective, cardioprotective, and anticoagulation properties. These examples also reveal the unlimited opportunity to future-proof public health by proactively mining, synthesizing, and cataloging the off-label treatment opportunities of thousands of safe, well-established, and affordable generic drugs.
\end{abstract}

(JMIRx Med 2020;1(1):e19583) doi: 10.2196/19583

\section{KEYWORDS}

COVID-19; drug repurposing; fibrates; histamine type-2 receptor antagonists; cimetidine; famotidine; fenofibrate; bezafibrate; dipyridamole; sildenafil

\section{Introduction}

Since the first report of a viral pneumonia of unknown cause in Wuhan, China, in December 2019, followed by the identification of the virus SARS-CoV-2 and the designation of the disease it causes as COVID-19, we have witnessed the rapid development of a pandemic that has become a global public health crisis. Although reported mortality rates are between $<1 \%$ and $27 \%$ depending on factors including age, gender, health status, and geographic location, this is likely an 
underestimation due to underreporting and limited serological testing [1]. With no approved preventive or therapeutic treatments available, the scale and human impact of the COVID-19 outbreak is daunting.

In this paper, we present candidates for a multifaceted approach to the management of COVID-19, based on repurposing tried and tested, affordable, widely available drugs with proven long-term safety, and mechanisms of action that address the underlying pathophysiology of the disease. Having recently published a short summary of our thesis [2], the current paper expands on why cimetidine or famotidine (histamine type-2 receptor antagonists), dipyridamole (antiplatelet agent), fenofibrate or bezafibrate (cholesterol/triglycerides-lowering agents), and sildenafil (phosphodiesterase-5 inhibitor) are worth considering for patients with COVID-19. The goal is to enable the rapid introduction of potentially beneficial, low-risk interventions. We also emphasize the urgency of redoubling efforts to mine, synthesize, and catalog the considerable existing body of evidence for promising treatments, in order to future-proof public health, based on robust science.

\section{Pathophysiology of COVID-19}

COVID-19 is characterized by prominent early respiratory signs and symptoms, including fever, cough, fatigue, and shortness of breath, that may deteriorate to acute respiratory distress syndrome (ARDS), coagulopathy, multiorgan failure, and other life-threatening sequelae (Table 1) [3,4]. On lung imaging, consolidation, ground glass opacity, and pulmonary infiltration are evident [3].

Table 1. Common clinical findings, complications, and laboratory abnormalities in patients with laboratory-confirmed COVID-19. CRP: C-reactive protein.

\begin{tabular}{|c|c|}
\hline System and clinical finding & Prevalence $(\%)$ \\
\hline \multicolumn{2}{|l|}{ Respiratory $[3,4]$} \\
\hline Fever & 79-98 \\
\hline Cough & $58-79$ \\
\hline Respiratory failure & 54 \\
\hline Acute respiratory distress syndrome & 30 \\
\hline Sputum production & $12-28$ \\
\hline \multicolumn{2}{|l|}{ Cardiovascular [3] } \\
\hline Cardiac failure & 23 \\
\hline Septic shock & 20 \\
\hline \multicolumn{2}{|l|}{ Multisystem [3,4] } \\
\hline Sepsis & 59 \\
\hline Fatigue & $20-44$ \\
\hline Coagulopathy & 19 \\
\hline \multicolumn{2}{|l|}{ Laboratory abnormalities $[3,4]$} \\
\hline Lactate dehydrogenase $>245 \mathrm{U} / \mathrm{L}$ & $67-73$ \\
\hline Procalcitonin $<0.1 \mathrm{ng} / \mathrm{mL}$ & 70 \\
\hline D-dimer $>1 \mu \mathrm{g} / \mathrm{mL}$ & $65-70$ \\
\hline Lymphopenia & $40-63$ \\
\hline Aspartate aminotransferase $>40 \mathrm{U} / \mathrm{L}$ & 37 \\
\hline Leucopenia & $22-25$ \\
\hline Raised CRP & $-{ }^{a}$ \\
\hline
\end{tabular}

${ }^{\mathrm{a}}$ Not available.

SARS-CoV-2 has also been isolated from feces, urine, blood, and ophthalmic secretions [5]; COVID-19 affects extrapulmonary organs and systems in ways that contribute significantly to overall morbidity and mortality. In a retrospective cohort study of 191 hospitalized patients with COVID-19 in Wuhan, sepsis was reported in $112(59 \%)$ patients admitted to the hospital, while respiratory failure (54\%), ARDS (31\%), heart failure (23\%), and septic shock (20\%) were reported in $\geq 20 \%$ of patients, significantly more frequently among those who died than in survivors (all $P<.001$ ) [3]. Similarly, coagulopathy (19\%) and acute cardiac (17\%) and renal $(15 \%)$ injury were widely observed, with a significantly higher incidence in nonsurvivors [3]. The fact that underlying cardiovascular, pulmonary, and renal disease have been associated with significantly increased mortality in COVID-19 patients and that abnormalities of various plasma inflammatory 
biomarkers (eg, lymphocyte count, C-reactive protein (CRP), procalcitonin, D-dimer, and aspartate aminotransferase) appear to be widespread $[3,4,6,7]$ highlights the multisystem nature of the disease and suggests that immune-mediated cytokine signaling and development of cytokine storm play a key role in driving disease progression [7].

Laboratory findings support the diverse effects of SARS-CoV-2, demonstrating, among other derangements, that leukopenia, lymphopenia, and thrombocytopenia, as well as elevated lactate dehydrogenase, CRP, and D-dimer, are significantly associated with a more severe course of disease $[3,4,6,8]$. Viral load also correlates strongly with disease severity (lung injury in particular) [9], while virus-induced endothelial dysfunction contributes to acute cardiac events that are a recognized complication of COVID-19 [10]. Although little attention has focused specifically on disturbed coagulation, evidence suggests that COVID-19 leads to profoundly altered coagulation function, with raised D-dimer, fibrinogen, and fibrin/fibrinogen degradation products $[11,12]$.

\section{Potential Therapies Within the Current Pharmacopoeia}

Widespread attention has been given to repurposing antimalarial chloroquine/hydroxychloroquine, the antibiotic azithromycin and, most recently, the antiparasitic agent ivermectin, for targeting COVID-19. All three drugs possess both anti-infective and immune-modulating properties [13-19]. While clinical evidence supporting their use individually or in combination in patients with COVID-19 have so far been inconclusive [13-19], partly due to methodological limitations, or are yet unavailable [20-22], this multitargeted approach of utilizing the safest drugs with pleiotropic effects is essential to reduce morbidity and mortality arising from COVID-19 infection. Indeed, a large number of approved drugs have mechanisms of action that could be harnessed to address the pathophysiology of COVID-19. Ideal choices would be safe and widely available generic drugs that are affordable in any setting, and especially for under-resourced populations. Below we summarize the safety profiles and rationale for repurposing several generic drugs that have demonstrated antiviral, anti-inflammatory, and/or cardio-, lung- or renal-protective effects. Some also lower elevated fibrinogen and D-dimer, which are associated with hypercoagulability and may contribute to the multiorgan failure seen in patients with COVID-19. Table 2 summarizes the physiological effects of these agents as they relate to potential benefits in patients with COVID-19.

Table 2. Approved indications and recognized physiological effects of drugs that could be considered for repurposing in patients with COVID-19.

\begin{tabular}{|c|c|c|c|c|}
\hline \multirow[t]{2}{*}{ Drug } & \multirow[t]{2}{*}{ Current indications } & \multirow[t]{2}{*}{ Proposed dose } & \multirow{2}{*}{$\begin{array}{l}\text { Demonstrated ef- } \\
\text { fects }^{\text {a }} \\
\text { A B C D E F G }\end{array}$} & \multirow[t]{2}{*}{ Notes } \\
\hline & & & & \\
\hline $\begin{array}{l}\text { Cimetidine } \\
\text { or famoti- } \\
\text { dine [23-46] }\end{array}$ & $\begin{array}{l}\text { Symptomatic man- } \\
\text { agement of GERD }\end{array}$ & $\begin{array}{l}\text { - Cimetidine } 200 \mathrm{mg} \text { four } \\
\text { times daily } \\
\text { Famotidine } 20-40 \mathrm{mg} \\
\text { twice daily }\end{array}$ & 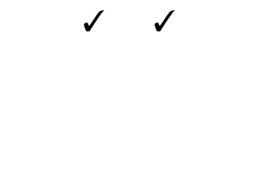 & $\begin{array}{l}\text { - Establish baseline prolactin levels and monitor peri- } \\
\text { odically } \\
\text { - } \quad \text { May increase serum concentrations of other drugs } \\
\text { - } \quad \text { Reduces dipyridamole absorption } \\
\text { - Relevant trials: NCT04504240 and NCT04370262 }\end{array}$ \\
\hline $\begin{array}{l}\text { Dipyri- } \\
\text { damole } \\
{[47-79]}\end{array}$ & $\begin{array}{l}\text { Antithrombotic fol- } \\
\text { lowing cardiac valve } \\
\text { replacement }\end{array}$ & $\begin{array}{l}\text { - } \quad 75 \mathrm{mg} \text { thrice daily OR 50- } \\
100 \mathrm{mg} \text { once weekly }\end{array}$ & $\checkmark \checkmark \checkmark \checkmark \checkmark$ & $\begin{array}{l}\text { - May cause headaches during the first week of use } \\
\text { - Taking with foods or antacids halves absorption } \\
\text { - Relevant trials: NCT04391179, NCT04424901, and } \\
\text { NCT04410328 }\end{array}$ \\
\hline $\begin{array}{l}\text { Fenofibrate } \\
\text { or bezafi- } \\
\text { brate [80-97] }\end{array}$ & Dyslipidemia & $\begin{array}{ll}\text { - } & \text { Fenofibrate } \leq 200 \mathrm{mg} / \text { day } \\
\text { - } & \text { Bezafibrate } 400 \mathrm{mg} \text { daily }\end{array}$ & $\checkmark \checkmark \checkmark \checkmark \checkmark$ & $\begin{array}{l}\text { - Significant reduction in D-dimer and fibrinogen } \\
\text { usually seen in days } \\
\text { - Relevant trial: NCT04517396 }\end{array}$ \\
\hline $\begin{array}{l}\text { Sildenafil } \\
\text { citrate } \\
{[98-112]}\end{array}$ & Erectile dysfunction & $\begin{array}{l}\text { - } 25 \mathrm{mg} \text { twice daily, on an } \\
\text { empty stomach }\end{array}$ & $\checkmark \checkmark$ & $\begin{array}{l}\text { - Avoid grapefruit juice (increases sildenafil levels) } \\
\text { - Cimetidine/famotidine increases sildenafil concen- } \\
\text { tration. If combined, consider lower sildenafil dose } \\
\text { - } \quad \text { Reven } 12.5 \text { mg twice daily } \\
\text { - Revant trials: NCT04304313 and NCT04489446 }\end{array}$ \\
\hline
\end{tabular}

\footnotetext{
${ }^{\mathrm{a}}$ Demonstrated effects are: A - preliminary efficacy in COVID-19 patients; B - anti-inflammatory effect; C - antiviral effect; D - anticoagulant effect; E - cardioprotective effect; $\mathrm{F}$ - renoprotective effect; G - lung protective effect.

${ }^{\mathrm{b}}$ GERD: gastroesophageal reflux disease.
}

\section{Cimetidine and Famotidine}

The histamine type- 2 receptor antagonists $\left(\mathrm{H}_{2} \mathrm{RAs}\right)$ cimetidine and famotidine were approved by the US Food and Drug Administration (FDA) in 1977 and 1986, respectively, and both have been widely used, for decades, for prevention and symptomatic management of gastroesophageal reflux disease (GERD) [23]. Ranitidine, another commonly used $\mathrm{H}_{2} \mathrm{RA}$, will soon be largely unavailable in the United States following an FDA recall based on high levels of a contaminant. Cimetidine 
is approved at daily doses of 200-400 $\mathrm{mg}$ for heartburn relief, and up to $1600 \mathrm{mg}$ for the short-term treatment of erosive GERD, while famotidine is approved at a dose of 10-20 mg twice daily (bid) for GERD, and 20-40 mg bid for erosive esophagitis [23]. Both drugs are available over the counter in the United States and much of the world, and are generally well tolerated, with most adverse events reported in $<1 \%$ of patients. Drug-drug interactions that may delay metabolism of other agents due to interaction with the cytochrome P450 system, limited antiandrogen effects, and stimulation of prolactin are recognized in particular with cimetidine. Prolactin levels should therefore be established at baseline and monitored periodically.

\section{Antiviral and Immunomodulatory Activity}

Beyond their role as gastric acid reducers, $\mathrm{H}_{2} \mathrm{RAs}$ have powerful modulatory effects on innate and adaptive immunity by interfering with the effects of histamine on a range of leukocytes. As such, they reverse histamine-mediated immunosuppression by stimulating the effector functions of a wide range of $\mathrm{T}$ and $B$ cells [24]. The resulting antiviral effects have been demonstrated in small studies in patients with herpes simplex virus (HSV) [25] and herpes zoster infection [26], and with human papillomavirus-related disorders [27]. In preclinical studies, cimetidine boosted immune cellular response when used as an adjuvant to viral vaccines for hepatitis B virus [28-31] and suppressed HIV replication in vitro [32]. Furthermore, intravenous ranitidine significantly increased the antibody response to vaccination in patients receiving tetanus toxoid before major abdominal surgery [33] and in patients with B-cell chronic lymphocytic leukemia receiving tetanus toxoid-conjugated Haemophilus influenzae type b vaccine $[34,35]$. Beyond antiviral effects, $\mathrm{H}_{2} \mathrm{RAs}$ have shown immunomodulatory effects in a range of cancers and allergic diseases, bone resorption, and during recovery from burn injury [24].

\section{Cardiovascular Protective Effects}

$\mathrm{H}_{2} \mathrm{RAs}$ also demonstrate a number of cardioprotective effects. A meta-analysis of 10 randomized controlled trials in patients with congestive heart failure, most of whom used famotidine, showed that orally administered $\mathrm{H}_{2} \mathrm{RAs}$ were associated with significant negative inotropic and chronotropic effects (reduction in heart rate vs placebo; $P=.02$ ), and also significantly decreased blood pressure and increased cardiac efficiency, presumably reducing myocardial oxygen requirement [36]. In another study, in critically ill patients, a single intravenous infusion of cimetidine, $200 \mathrm{mg}$, reduced systolic, diastolic, and mean arterial blood pressure, and raised heart rate [37]. High-dose intravenous cimetidine (200 mg four times daily [qid]) administered after elective cardiac bypass surgery was also shown to reduce levels of proinflammatory mediators (neutrophil elastase, interleukin-8, CRP) with no adverse effects, suggesting the potential to improve cardiac outcomes under certain physiological conditions [38].

Furthermore, $\mathrm{H}_{2}$ RAs also strongly inhibit platelet aggregation in vitro $[39,40]$ and ranitidine, in combination with hydrocortisone, has been shown to reduce complications after arterial thrombolysis in pediatric patients who developed arterial obstruction after cardiac catheterization [41]. These agents may therefore exert stabilizing effects on coagulation in patients with disturbed clotting function, the caveat being the potential for thrombocytopenia and/or hemolytic anemia [42-46].

\section{Dipyridamole}

The antiplatelet agent and phosphodiesterase inhibitor dipyridamole was first approved in 1961 and is indicated in the United States at doses of $75-100 \mathrm{mg}$ qid with warfarin to decrease thrombotic risk following cardiac valve replacement [47]. It is also sold in the United States as a combined product, Aggrenox (aspirin $25 \mathrm{mg} /$ extended-release dipyridamole 200 $\mathrm{mg}$ ), which was approved in 1999 and is taken twice daily to reduce stroke risk [48]. Outside the United States, including in Europe, dipyridamole is available as a single agent; in Russia it is also approved as an antiviral agent [49]. Within the 200-400 $\mathrm{mg}$ daily dose range, dipyridamole is considered safe based on decades of clinical experience: adverse events are usually limited and transient, the most common being dizziness, gastrointestinal disturbance, headache, and skin rash [50]. The pleiotropic effects of dipyridamole derive from increased intracellular levels of cyclic adenosine monophosphate (cAMP) and cyclic guanine monophosphate (cGMP), which lead to anti-inflammatory, antioxidant, anticoagulation, and vasodilatory effects [51].

\section{Antiviral Effects}

Dipyridamole possesses very broad spectrum antiviral activity as shown in numerous preclinical studies that demonstrated efficacy, alone or as a potentiator of other agents, against HSV, HIV, varicella zoster, cytomegalovirus, and mengovirus, as well as a range of viruses from the picornavirus, togavirus, orthomyxovirus, paramyxovirus, and pox virus families [52-56]. Induction of interferon responses have been identified as an important contributory factor to its antiviral effects [57]. A number of clinical studies have confirmed the antiviral effects of dipyridamole which, at a dose of 8-100 mg weekly, significantly reduced the risk of acute respiratory diseases, including influenza, when administered prophylactically to at-risk individuals [57-59].

\section{Effects in Patients With COVID-19}

A recent study in patients with COVID-19 in China illustrates that dipyridamole suppressed SARS-CoV-2 replication in vitro, induced potent antiviral immunity, and improved survival in a mouse model of pneumonia [60]. In a clinical study of 12 COVID-19 patients that was conducted alongside these preclinical investigations and reported within the same publication, dipyridamole increased lymphocyte and platelet counts, decreased D-dimer levels, and markedly improved clinical outcomes when dosed at $50 \mathrm{mg}$ three times daily for 1 week. In this small but very promising study, three of the six patients with severe disease were discharged, and four (33\%) mild cases achieved clinical remission. Data from an ongoing multicenter study examining dipyridamole in 460 patients with COVID-19 in China (ChiCTR2000030055) will add to our understanding [61]. 


\section{Anti-Inflammatory, Antioxidant, and Endothelial Protective Effects}

A large number of preclinical studies have demonstrated that dipyridamole limits oxidative stress in platelets and endothelial cells, inhibits release of proinflammatory cytokines, and reduces inflammatory responses, independent of its antiplatelet activity [51,62]. This has implications for a wide range of pathologies beyond thrombosis prevention, including reduced brain endothelial injury after inflammatory and metabolic insult [63]. The combination of dipyridamole with prednisolone has been shown to lead to significant reductions in interferon- $\gamma$, interleukin-6, and CRP in subjects with periodontitis [64], and widening of the therapeutic window of glucocorticoid activity [65]. This is due to the ability of dipyridamole to selectively potentiate the effects of prednisolone and other glucocorticoids. Dipyridamole was also shown to increase extracellular levels of the immune-dampening nucleoside, adenosine, and decrease CD4+ T cell activation by $11.1 \%(P=.006)$ in patients with chronic HIV infection receiving antiviral therapy [66].

\section{Antihypercoagulation Effects}

Hypercoagulability is a potentially life-threatening complication of certain clinical conditions and a serious risk during mechanical circulatory support. Besides its well-established antiplatelet effects, dipyridamole has shown efficacy as one component of a near-universal anticoagulant when administered in combination with citrate, theophylline, and adenosine (as CTAD [citrate-theophylline-adenosine-dipyridamole]) in veterinary practice $[67,68]$ and in human subjects [69]. When combined with heparin or aspirin in small numbers of pediatric patients on circulatory support [70] or with disseminated intravascular coagulation [71], dipyridamole has led to clinical recovery in the majority of subjects.

\section{Cardioprotective Effects}

Adenosine serves as an endogenous cardioprotective agent. Disturbances of adenosine in the diseased myocardium include raised plasma levels and decreased gene expression of certain receptors in patients with chronic heart failure $[72,73]$ as well as impaired vasodilation in patients with hyperhomocysteinemia [74]. By increasing adenosine levels in vivo using dipyridamole $\leq 300 \mathrm{mg}$ daily, it was possible to improve numerous functional measures of disease severity in cases of chronic heart failure $[72,73]$ and restore adenosine-induced vasodilation in hyperhomocysteinemic patients [74], highlighting the potential to augment endogenous cardioprotective mechanisms. The clinical effects of dipyridamole in mild-to-moderate chronic heart failure were also revealed in a trial that randomized 28 patients to their usual treatment with or without the addition of dipyridamole, 75 or $300 \mathrm{mg} / \mathrm{day}$, for 1 year [75]. Cardiac ejection fraction, left ventricular systolic diameter, maximal oxygen consumption, and plasma B-type natriuretic peptide level were all significantly improved versus baseline and control in dipyridamole-treated patients, in a broadly dose-dependent manner, indicating a role for supplementary dipyridamole in improving the pathophysiology of chronic heart failure.

\section{Renoprotective Effects}

In patients with kidney disease, dipyridamole reduces proteinuria and improves renal function by inhibiting platelet activation and enhancing nitric oxide (NO)-induced vasodilation. A prospective study of $>28,000$ patients with advanced chronic kidney disease (CKD) in Taiwan found that dipyridamole significantly reduced the risk of progression to long-term dialysis and predialysis death (hazard ratios 0.96 and 0.91 , respectively; both $P<.05$ versus nonuse) [76]. In another large Taiwanese study in patients with advanced CKD, dipyridamole decreased the risk of progression to end-stage renal disease by approximately $15 \%$ and reduced all-cause mortality by $23.5 \%$ $(P=.001)$ [77]. There is also evidence that the vascular renoprotective effects may benefit patients with immunoglobulin A nephropathy (when given with warfarin) [78] and protect against preeclampsia [79].

\section{Fenofibrate and Bezafibrate}

The cholesterol-lowering agents fenofibrate and bezafibrate are indicated for the treatment of dyslipidemias. Fenofibrate is a peroxisome proliferator-activated receptor- $\alpha$ agonist that was approved in the United States in 1993 and is used for the treatment of primary hypertriglyceridemia, mixed dyslipidemia, and severe hypertriglyceridemia (up to $160 \mathrm{mg}$ once daily) [80]. Abnormal liver tests, elevated liver enzymes and creatine phosphokinase, and rhinitis are the most frequent adverse events. Rare instances of myositis or rhabdomyolysis have been reported, and potentiation of coumarin anticoagulants can cause bleeding, so a reduced anticoagulant dose is advised [80]. Bezafibrate is currently not approved for use in the United States but is commonly used in Europe.

Numerous preclinical studies support a role for fenofibrate in attenuating vascular endothelial dysfunction, oxidative stress, and inflammation across a range of organs and tissues, with clinical evidence of cardioprotection and some antiviral effects [81].

\section{Antiviral Effects}

A meta-analysis of eight observational studies of fibrates, with or without statins, in patients with hepatitis $\mathrm{C}$ virus infection, revealed a significant reduction in viral load, with bezafibrate demonstrating the greatest antiviral efficacy among the medications tested. The antiviral potency of bezafibrate was confirmed in both Asian and European study populations. Interestingly, the significant clinical effect was found despite the failure of in vitro studies to demonstrate a significant effect [82].

\section{Anti-Inflammatory Effects}

The anti-inflammatory properties of fibrates that underpin some of the macrovascular benefits also translate into improved clinical outcomes in patients with microvascular disease. In in vitro studies, fenofibrate demonstrated potentially protective effects on the renal and retinal microvasculature by suppressing inflammation and apoptosis in human glomerular microvascular cells and reducing retinal microvascular inflammation [83,84], while bezafibrate decreased the number of circulating proinflammatory monocytes in patients with type 2 diabetes [85]. A beneficial modulatory role for fenofibrate in renal 
fibrosis and inflammation has also been proposed, with further studies required to elucidate the mechanisms involved [81].

\section{Cardioprotective Effects}

Preclinical studies provide evidence that fenofibrate can protect against cardiac ischemia-reperfusion injury and subsequent arrhythmias and heart failure, autoimmune myocarditis, and hypertension $[81,86,87]$. In the clinical setting, a meta-analysis of studies in which fibrates were used for primary prevention of atherosclerotic cardiovascular disease reported a significant $16 \%$ decrease in the combined outcome of cardiovascular death, nonfatal myocardial infarction, and nonfatal stroke [88] while a $12 \%$ reduction in these outcomes was reported when fibrates were used in secondary prevention [89].

\section{Anticoagulation Effects}

Robust data indicate that fibrates lower plasma fibrinogen levels to a significant degree, independent of their lipid-lowering effects [90-95]. In a meta-analysis of 22 trials, representing $>2700$ participants, fibrates (fenofibrate and bezafibrate) demonstrated a significantly greater effect than statins in lowering plasma fibrinogen concentrations (weighted mean difference $-40.7 \mathrm{mg} / \mathrm{dL}, P<.001$ ) [93]. Data from smaller studies focusing on the antihyperlipidemic effects of fibrates (fenofibrate $200 \mathrm{mg}$ daily; bezafibrate $400 \mathrm{mg}$ daily) show concurrent, significant reductions in plasma fibrinogen levels [90-92,94]. Of note is a study that reported an increase in fibrinogen levels among patients taking statins [94], which could be a concern in elderly patients with COVID-19, many of whom are likely to be taking statins.

In patients with metabolic syndrome, which represents a hypercoagulable state accompanied by inflammation and endothelial dysfunction, fenofibrate reduced concentrations of thrombin-activatable fibrinolysis inhibitor, improved endothelial function [96], and significantly reduced fibrinogen and D-dimer concentrations [97], suggesting potential anticoagulant and cardiovascular protective effects. This potential was borne out in a short-term randomized controlled trial of patients with acute ST-elevation myocardial infarction, in whom bezafibrate lowered fibrinogen concentration more effectively than conventional therapy $(P<.001)$, with significantly greater reductions in the incidence of angina $(56 \%$ vs $4 \%, P<.001)$ and left ventricular failure ( $24 \%$ vs $4 \%, P=.049)$ [95].

\section{Sildenafil Citrate}

The phosphodiesterase-5 inhibitor (PDE5 inhibitor) sildenafil citrate is a vasodilator that was approved by the FDA in 1998 for the treatment of erectile dysfunction, at a dose of 25-100 $\mathrm{mg}$ once daily [98]. More recently, an indication for pulmonary arterial hypertension (PAH) was added in 2005, with an oral dosing of 5 or $20 \mathrm{mg}$ thrice daily, or $2.5 \mathrm{mg}$ or $10 \mathrm{mg}$ as intravenous bolus [99]. In erectile dysfunction, orally administered sildenafil has an onset of action within 30 minutes, maximum effect at 1 hour, and duration of effect of 4-6 hours; in PAH, the pharmacodynamics are similar although peak effect occurs 1-2 hours after dosing, and blood pressure levels return to baseline levels within 8 hours $[98,99]$. The most common dose-dependent adverse reactions $(\geq 5 \%)$ include headache, flushing, dyspepsia, visual disturbance, and nasal congestion.
CYP3A4 inhibitors are known to potentiate sildenafil, while sildenafil potentiates the hypotensive effects of nitrates and alpha-blockers.

Sildenafil inhibits breakdown of cGMP through competitive binding at the phosphodiesterase binding site. It therefore influences platelet activation, proliferation of $\mathrm{T}$ cells, and production of proinflammatory cytokines, leading to a broad range of anti-inflammatory, antioxidant, vasodilatory, and other actions in many body systems [100]. An ongoing phase 3 trial of sildenafil, $100 \mathrm{mg}$ daily for 14 days, in patients with COVID-19 (NCT04304313) will help clarify its potential benefits in this disease [101].

\section{Immunomodulatory Effects}

In vitro human studies indicate that sildenafil potentiates the ability of regulatory $\mathrm{T}$ cells to downregulate $\mathrm{T}$ effector cell proliferation, while clinical findings include reduced lymphocyte count and induction of malignant cell apoptosis in a patient with B-cell chronic lymphocytic leukemia and in patients with Waldenstrom's macroglobulinemia [100]. It was hypothesized that these effects were mediated by synthesis and release of cytokines. Sustained increase in NO production, and decreased vascular inflammatory markers, have also been reported in patients with type 2 diabetes receiving sildenafil [102,103].

\section{Cardiovascular Protective Effects}

One-time and long-term administration of PDE5 inhibitors in patients at high cardiovascular risk can improve endothelial function, reduce inflammatory mediators, and increase endothelial regenerative capacity, which may be sustained for several months following treatment discontinuation, with potential applications in a range of cardiovascular disorders [104,105]. Cardioprotective effects include improved symptoms and cardiac contractility in patients with systolic heart failure, reduced myocardial infarct size, reduced blood pressure, and limitation of ischemia-driven ventricular arrhythmias, with reduction in cardiovascular events and mortality in high-risk patients [106-108]. In a British study that followed nearly 6000 men with type 2 diabetes over 7.5 years, the use of PDE5 inhibitors was associated with lower mortality risk overall (adjusted hazard ratio $0.54, P=.002$ ) and in those with a history of acute myocardial infarction (heart rate $=0.60, P=.001$ ) [108]. These effects are believed to result from improved pulmonary circulation, as well as direct action on the myocardium, independent of the vasculature [106].

\section{Lung-Protective Effects}

Studies demonstrating sildenafil's efficacy and tolerability in PAH continue to accrue, and a 2019 Cochrane systematic review and meta-analysis comprising 36 studies of nearly 3000 patients concluded that those with PAH who received PDE5 inhibitors were $22 \%$ less likely to die in the short-term than those receiving placebo [109]. Additionally, a network meta-analysis reported moderate-level evidence that sildenafil may reduce mortality in idiopathic pulmonary fibrosis, an interstitial lung disease with high mortality [110]. A single case report of a 55-year-old physician with an atypical respiratory infection and apparently normal pulmonary arterial blood pressure who experienced marked symptomatic and functional improvement within 24 
hours of starting tadalafil highlights the potential benefits of PDE5 inhibitors in this indication [111].

\section{Renoprotective Effects}

Preliminary evidence suggests that the clinical efficacy of PDE5 inhibitors in CKD extends beyond antihypertensive effects to active renoprotection. In preclinical studies, PDE5 inhibitors suppressed mesangial cell proliferation and extracellular matrix expansion, reduced renal cell apoptosis, and decreased oxidative stress and inflammation [107]. A post hoc examination of this class of medications in a randomized controlled trial also revealed improved kidney function and functional capacity, and a trend toward reduced mortality, in patients with PAH who received sildenafil treatment [112]. Few, if any, clinical studies of PDE5 inhibitors in patients with acute kidney disease have been published. Ongoing clinical trials (eg, NCT04304313) will shed further light on this and may reveal information that could be applied in the treatment of patients with COVID-19 [101].

\section{Conclusions}

Under the extraordinary COVID-19 pandemic conditions that have brought the world to the brink of an irreversible crisis, time is of the essence for the success of life-saving efforts. Until a vaccine is developed to treat this disease, the urgency of finding safe and effective treatments cannot be overstated. To ensure that patients with COVID-19 have rapid access to safe treatments, and to ensure the responsible use of available resources, it would be wise to mine the existing pharmacopeia for safe generic drugs that address the pathophysiologies underlying COVID-19. Moreover, beyond the current emergency there remains the likelihood of future re-emergence of another coronavirus or similar virus. The efforts we make now to facilitate access to information on the off-label applications of well-understood drugs, regardless of the manner in which the information has been discovered, are an investment in our future health that also addresses current needs. While clinical trials to assess efficacy will be important in due course, judicious use of one or more of these approved drugs, with caution toward potential interactions with concomitant medications, represents a rational and ethical approach that may prove effective in the short term. There is no time to waste and little to lose.

\section{Epilogue}

Since the initial submission of this article as a preprint in April 2020, new developments and evidence have emerged that further support the therapeutic potential of the drugs proposed in this paper for use in the treatment of COVID-19. The new developments and evidence are summarized below and are current as of August 31, 2020.

\section{Dipyridamole}

Research aimed at assessing the therapeutic potential of dipyridamole continues. One ongoing phase 3 clinical trial (ClinicalTrials.gov ID NCT04410328) randomized patients $(\mathrm{n}=132)$ to receive dipyridamole ER $200 \mathrm{mg}$ and aspirin $25 \mathrm{mg}$ orally/enterally plus standard care or standard care alone [113]. Researchers are also evaluating dipyridamole in two other ongoing clinical trials with a focus on determining the extent to which the drug can reduce excessive coagulation [114] and treat respiratory tract infection and circulatory dysfunction caused by SARS-CoV-2 [115] in hospitalized COVID-19 patients.

\section{Famotidine}

The therapeutic potential of famotidine (combined with cetirizine) in COVID-19 treatment was recently boosted by an American cohort study evaluating the efficacy of dual-histamine blockade in patients with COVID-19. In the study, hospitalized COVID-19 patients with severe-to-critical symptoms were treated with cetirizine $10 \mathrm{mg}$ and famotidine $20 \mathrm{mg}$ bid in addition to standard care. This combination reduced symptom progression when compared to published reports of COVID-19 patients [116]. The safety and efficacy of famotidine in COVID-19 is further supported by a case series of 10 US patients with COVID-19 who self-administered high-dose oral famotidine ( $80 \mathrm{mg}$ thrice daily was the most frequent regimen used) for 11 days. All patients reported marked improvements in COVID-19-related symptoms, suggesting that high-dose oral famotidine is well tolerated and associated with improved patient-reported outcomes in nonhospitalized patients with COVID-19 [117].

Another case series of 14 COVID-19 hospitalized patients from Beloit Memorial Hospital, United States, reported improvement in supplemental oxygen requirements, ground-glass computed tomography findings, and serum levels of lactate dehydrogenase, ferritin, CRP, D-dimer, and lymphocytes in patients who received famotidine $80 \mathrm{mg}$ qid plus celecoxib (as adjuvant therapy) [118]. This treatment combination was associated with a 100\% survival rate. Similar clinical improvements have been reported by Freedberg et al [119] among hospitalized COVID-19 patients. Despite clinical evidence suggesting that famotidine may mitigate COVID-19, its mechanism of action remains a matter of debate. A recent study by Malone et al [120] suggests that the drug's therapeutic action in COVID-19 involves on-target histamine receptor- $\mathrm{H} 2$ activity, which has face validity since the development of clinical symptoms involves dysfunctional mast cell activation and histamine release.

\section{Fenofibrate}

Researchers from the Hebrew University of Jerusalem, Israel, and Icahn School of Medicine at Mount Sinai (United States) studied the metabolic changes induced by SARS-CoV-2 infection in bronchial epithelial cells using lung biopsy samples from patients with COVID-19. The researchers reported a significant metabolic response in SARS-CoV-2-infected lungs in addition to changes in lipid metabolism and the induction of inositol-requiring enzyme-1 and RNA-activated protein kinase pathways of endoplasmic stress. The study showed that fenofibrate reversed the metabolic changes induced by SARS-CoV-2, blocking viral production and suppressing the pathogenesis of COVID-19 in lung tissue [121].

\section{Sildenafil}

A recent systematic review carried out by researchers from the University of Rome, Italy, consolidated evidence of the involvement of the NO-cGMP-PDE5 axis in the 
pathophysiology of COVID-19, presenting ongoing clinical trials aimed at modulating this axis, including the DEDALO (silDEnafil administration in DiAbetic and dysmetaboLic patients with COVID-19) trial [122]. Reviewed data indicate that PDE5 inhibitors could be effective in managing patients with COVID-19 by counteracting the Ang-II-mediated downregulation of the AT-1 receptor, exhibit action on monocyte switching, reducing proinflammatory cytokines and interstitial infiltration; and inhibit the transition of endothelial and smooth muscle cells to mesenchymal cells in the pulmonary artery, preventing clotting and thrombotic complications. With sildenafil's low cost, well-established safety, wide availability, and efficacy arising from observational studies and clinical trials (including the new "Sildenafil in COVID-19" trial; ClinicalTrials.gov ID NCT04489446), it, and other PDE5 inhibitors, could potentially become key COVID-19 treatment options [122,123].

\section{Conflicts of Interest}

None declared.

\section{References}

1. Auwaerter PG. Johns Hopkins ABX Guide: Coronavirus COVID-19 (SARS-CoV-2). The Johns Hopkins University. 2020 Aug. URL: http://www.hopkinsguides.com/hopkins/view/Johns Hopkins ABX Guide/540747/all/ Coronavirus COVID 19 SARS CoV 2 [accessed 2020-03-31]

2. Rogosnitzky M, Berkowitz E, Jadad A. Delivering Benefits at Speed Through Real-World Repurposing of Off-Patent Drugs: The COVID-19 Pandemic as a Case in Point. JMIR Public Health Surveill 2020 May 13;6(2):e19199 [FREE Full text] [doi: 10.2196/19199] [Medline: 32374264]

3. Zhou F, Yu T, Du R, Fan G, Liu Y, Liu Z, et al. Clinical course and risk factors for mortality of adult inpatients with COVID-19 in Wuhan, China: a retrospective cohort study. The Lancet 2020 Mar;395(10229):1054-1062. [doi: 10.1016/S0140-6736(20)30566-3]

4. Huang C, Wang Y, Li X, Ren L, Zhao J, Hu Y, et al. Clinical features of patients infected with 2019 novel coronavirus in Wuhan, China. The Lancet 2020 Feb;395(10223):497-506. [doi: 10.1016/s0140-6736(20)30183-5]

5. Wang W, Xu Y, Gao R, Lu R, Han K, Wu G, et al. Detection of SARS-CoV-2 in Different Types of Clinical Specimens. JAMA 2020 May 12;323(18):1843-1844 [FREE Full text] [doi: 10.1001/jama.2020.3786] [Medline: $\underline{32159775]}$

6. Epidemiology Working Group for NCIP Epidemic Response, Chinese Center for Disease Control and Prevention. [The epidemiological characteristics of an outbreak of 2019 novel coronavirus diseases (COVID-19) in China]. Zhonghua Liu Xing Bing Xue Za Zhi 2020 Feb 10;41(2):145-151. [doi: 10.3760/cma.j.issn.0254-6450.2020.02.003] [Medline: 32064853]

7. Madjid M, Safavi-Naeini P, Solomon SD, Vardeny O. Potential Effects of Coronaviruses on the Cardiovascular System: A Review. JAMA Cardiol 2020 Jul 01;5(7):831-840. [doi: 10.1001/jamacardio.2020.1286] [Medline: 32219363]

8. Zhang F, Yang D, Li J, Gao P, Chen T, Cheng Z. Myocardial injury is associated with in-hospital mortality of confirmed or suspected COVID-19 in Wuhan, China: A single center retrospective cohort study. medRxiv 2020 Mar:e [FREE Full text] [doi: 10.1101/2020.03.21.20040121]

9. Liu Y, Yang Y, Zhang C, Huang F, Wang F, Yuan J, et al. Clinical and biochemical indexes from 2019-nCoV infected patients linked to viral loads and lung injury. Sci China Life Sci 2020 Mar 11;63(3):364-374 [FREE Full text] [doi: 10.1007/s11427-020-1643-8] [Medline: 32048163]

10. Chen L, Li X, Chen M, Feng Y, Xiong C. The ACE2 expression in human heart indicates new potential mechanism of heart injury among patients infected with SARS-CoV-2. Cardiovasc Res 2020 May 01;116(6):1097-1100 [FREE Full text] [doi: 10.1093/cvr/cvaa078] [Medline: 32227090]

11. Han H, Yang L, Liu R, Liu F, Wu K, Li J, et al. Prominent changes in blood coagulation of patients with SARS-CoV-2 infection. Clin Chem Lab Med 2020 Jun 25;58(7):1116-1120. [doi: 10.1515/cclm-2020-0188] [Medline: 32172226]

12. Gao Y, Li T, Han M, Li X, Wu D, Xu Y, et al. Diagnostic utility of clinical laboratory data determinations for patients with the severe COVID-19. J Med Virol 2020 Jul 17;92(7):791-796 [FREE Full text] [doi: 10.1002/jmv.25770] [Medline: 32181911]

13. Gao J, Tian Z, Yang X. Breakthrough: Chloroquine phosphate has shown apparent efficacy in treatment of COVID-19 associated pneumonia in clinical studies. Biosci Trends 2020 Mar 16;14(1):72-73 [FREE Full text] [doi: 10.5582/bst.2020.01047] [Medline: 32074550]

14. Gautret P, Lagier J, Parola P, Hoang VT, Meddeb L, Mailhe M, et al. Hydroxychloroquine and azithromycin as a treatment of COVID-19: results of an open-label non-randomized clinical trial. International Journal of Antimicrobial Agents 2020 Jul;56(1):105949. [doi: 10.1016/j.ijantimicag.2020.105949]

15. Gautret P, Lagier J, Parola P, Hoang VT, Meddeb L, Sevestre J, et al. Clinical and microbiological effect of a combination of hydroxychloroquine and azithromycin in 80 COVID-19 patients with at least a six-day follow up: A pilot observational study. Travel Med Infect Dis 2020 Apr;34:101663 [FREE Full text] [doi: 10.1016/j.tmaid.2020.101663] [Medline: 32289548]

16. Chen Z, Hu J, Zhang Z, Jiang S, Han S, Yan D. Efficacy of hydroxychloroquine in patients with COVID-19: results of a randomized clinical trial. MedRxiv 2020 Apr:e [FEE Full text] [doi: 10.1101/2020.03.22.20040758] 
17. Huang M, Tang T, Pang P, Li M, Ma R, Lu J, et al. Treating COVID-19 with Chloroquine. J Mol Cell Biol 2020 May 18;12(4):322-325 [FREE Full text] [doi: $10.1093 / j \mathrm{mcb} / \mathrm{mjaa} 014]$ [Medline: $\underline{\text { 32236562] }}$

18. Magagnoli J, Narendran S, Pereira F, Cummings TH, Hardin JW, Sutton SS, et al. Outcomes of Hydroxychloroquine Usage in United States Veterans Hospitalized with COVID-19. Med (N Y) 2020 Jun 05:e [FREE Full text] [doi: 10.1016/j.medj.2020.06.001] [Medline: $\underline{32838355}$ ]

19. Mahevas M, Tran V, Roumier M, Chabrol A, Paule R, Guillaud C. No evidence of clinical efficacy of hydroxychloroquine in patients hospitalized for COVID-19 infection with oxygen requirement: results of a study using routinely collected data to emulate a target trial. medRxiv 2020 Apr:e [FREE Full text] [doi: 10.1101/2020.04.10.20060699]

20. Chaccour C, Hammann F, Ramón-García S, Rabinovich NR. Ivermectin and COVID-19: Keeping Rigor in Times of Urgency. Am J Trop Med Hyg 2020 Jun;102(6):1156-1157 [FREE Full text] [doi: 10.4269/ajtmh.20-0271] [Medline: $\underline{32314704]}$

21. Caly L, Druce JD, Catton MG, Jans DA, Wagstaff KM. The FDA-approved drug ivermectin inhibits the replication of SARS-CoV-2 in vitro. Antiviral Res 2020 Jun;178:104787 [FREE Full text] [doi: 10.1016/j.antiviral.2020.104787] [Medline: $\underline{32251768]}$

22. Patrì A, Fabbrocini G. Hydroxychloroquine and ivermectin: A synergistic combination for COVID-19 chemoprophylaxis and treatment? J Am Acad Dermatol 2020 Jun;82(6):e221 [FREE Full text] [doi: 10.1016/j.jaad.2020.04.017] [Medline: $\underline{32283237]}$

23. Gastric acid reducers. Merck Manual Professional Version. 2020. URL: https://www.merckmanuals.com/professional/ gastrointestinal-disorders/gastritis-and-peptic-ulcer-disease/drug-treatment-of-gastric-acidity\#v892554 [accessed 2020-03-31]

24. Jafarzadeh A, Nemati M, Khorramdelazad H, Hassan ZM. Immunomodulatory properties of cimetidine: Its therapeutic potentials for treatment of immune-related diseases. Int Immunopharmacol 2019 May;70:156-166. [doi:

10.1016/j.intimp.2019.02.026] [Medline: 30802678]

25. Kurzrock R, Auber M, Mavligit GM. Cimetidine therapy of herpes simplex virus infections in immunocompromised patients. Clin Exp Dermatol 1987 Sep;12(5):326-331. [doi: 10.1111/j.1365-2230.1987.tb02501.x] [Medline: 3446417]

26. Kapińska-Mrowiecka M, Turowski G. [Efficacy of cimetidine in treatment of Herpes zoster in the first 5 days from the moment of disease manifestation]. Pol Tyg Lek 1996 Jun;51(23-26):338-339. [Medline: 9273526]

27. Harcourt J, Worley G, Leighton S. Cimetidine treatment for recurrent respiratory papillomatosis. International Journal of Pediatric Otorhinolaryngology 1999 Dec;51(2):109-113. [doi: 10.1016/s0165-5876(99)00279-7]

28. Niu X, Yang Y, Wang J. Synergistic and additive effects of cimetidine and levamisole on cellular immune responses to hepatitis B virus DNA vaccine in mice. Scand J Immunol 2013 Feb 24;77(2):84-91 [FREE Full text] [doi: 10.1111/sji.12018] [Medline: 23298196]

29. Xie X, Geng S, Liu H, Li C, Yang Y, Wang B. Cimetidine synergizes with Praziquantel to enhance the immune response of HBV DNA vaccine via activating cytotoxic CD8(+) T cell. Hum Vaccin Immunother 2014 Mar 18;10(6):1688-1699 [FREE Full text] [doi: 10.4161/hv.28517] [Medline: 24643207]

30. Zhang W, Wang J, Su B, Li R, Ding Z, Kang Y, et al. Cimetidine augments Th1/Th2 dual polarized immune responses to recombinant HBV antigens. Vaccine 2011 Jun 24;29(29-30):4862-4868. [doi: 10.1016/j.vaccine.2011.03.091] [Medline: 21481324]

31. Wang J, Su B, Ding Z, Du X, Wang B. Cimetidine enhances immune response of HBV DNA vaccination via impairment of the regulatory function of regulatory T cells. Biochem Biophys Res Commun 2008 Aug 01;372(3):491-496. [doi: 10.1016/j.bbrc.2008.04.191] [Medline: 18502198]

32. Bourinbaiar AS, Fruhstorfer EC. The effect of histamine type 2 receptor antagonists on human immunodeficiency virus (HIV) replication: Identification of a new class of antiviral agents. Life Sciences 1996 Nov;59(23):PL365-PL370. [doi: 10.1016/s0024-3205(96)00553-x]

33. Nielsen HJ, Hammer JH, Moesgaard F, Heron I, Kehlet H. Ranitidine improves postoperative suppression of antibody response to preoperative vaccination. Surgery 1992 Jan;111(1):69-73. [Medline: 1728077]

34. Van der Velden AMT, Van Velzen-Blad H, Claessen AME, Van der Griend R, Oltmans R, Rijkers GT, et al. The effect of ranitidine on antibody responses to polysaccharide vaccines in patients with B-cell chronic lymphocytic leukaemia. Eur J Haematol 2007 Jul;79(1):47-52. [doi: 10.1111/j.1600-0609.2007.00862.x] [Medline: 17532765]

35. Jurlander J, de Nully Brown P, Skov PS, Henrichsen J, Heron I, Obel N, et al. Improved vaccination response during ranitidine treatment, and increased plasma histamine concentrations, in patients with B cell chronic lymphocytic leukemia. Leukemia 1995 Nov;9(11):1902-1909. [Medline: 7475282]

36. Zhang J, Cai W, Zhang Z, Wang P, Lin X, Feng J, et al. Cardioprotective effect of histamine H2 antagonists in congestive heart failure: A systematic review and meta-analysis. Medicine (Baltimore) 2018 Apr;97(15):e0409 [FREE Full text] [doi: 10.1097/MD.0000000000010409] [Medline: 29642208]

37. Breuer HM, Hartung H, Goeckenjan G, Abendroth R, Curtius JM, Trampisch HJ, et al. [Cimetidine and ranitidine in intensive care patients. Double-blind randomized cross-over study on intravenous administration: hemodynamics, plasma coagulation, blood gases and acid-base status]. Dtsch Med Wochenschr 1985 Jul 26;110(30):1151-1156. [doi: 10.1055/s-2008-1068976] [Medline: 3893961] 
38. Tayama E, Hayashida N, Fukunaga S, Tayama K, Takaseya T, Hiratsuka R, et al. High-dose cimetidine reduces proinflammatory reaction after cardiac surgery with cardiopulmonary bypass. The Annals of Thoracic Surgery 2001 Dec;72(6):1945-1949. [doi: 10.1016/s0003-4975(01)03225-8]

39. Nakamura K, Kariyazono H, Shinkawa T, Yamaguchi T, Yamashita T, Ayukawa O, et al. Inhibitory effects of H2-receptor antagonists on platelet function in vitro. Hum Exp Toxicol 1999 Aug 02;18(8):487-492. [doi: 10.1191/096032799678847069] [Medline: 10462360]

40. Mikhailidis DP, Christofides J, Barradas MA, Jeremy JY, Dilawari J, Dandona P. The effect of cimetidine on platelet function: a study involving gastric fluid measurements. Agents and Actions 1986 Oct;19(1-2):34-41. [doi: $10.1007 / \mathrm{bf01977253}$

41. Noori N, Miri Aliabad G, Mohammadi M, Mahjoubifard M, Jahangiri Fard A. The effects of ranitidine and hydrocortisone on the complications of femoral artery obstruction treated by streptokinase following cardiac catheterization in pediatric patients with congenital heart diseases. Iran Red Crescent Med J 2013 Feb 19;15(2):117-121 [FREE Full text] [doi: 10.5812/ircmj.7248] [Medline: 24693416]

42. Glotzbach RE. Cimetidine-induced thrombocytopenia. South Med J 1982 Feb;75(2):232-234. [doi: 10.1097/00007611-198202000-00030] [Medline: 7058369]

43. Gentilini G, Curtis BR, Aster RH. An antibody from a patient with ranitidine-induced thrombocytopenia recognizes a site on glycoprotein IX that is a favored target for drug-induced antibodies. Blood 1998 Oct 01;92(7):2359-2365. [Medline: 9746775]

44. Gafter U, Zevin D, Komlos L, Livni E, Levi J. Thrombocytopenia associated with hypersensitivity to ranitidine: possible cross-reactivity with cimetidine. Am J Gastroenterol 1989 May;84(5):560-562. [Medline: 2719014]

45. Takimoto R, Mogi Y, Kura T, Niitsu Y. [Hemolytic anemia and thrombocytopenia induced by cimetidine: recurrence with ranitidine administration]. Rinsho Ketsueki 1997 Feb;38(2):124-128. [Medline: 9059066]

46. Hoste L, George I. Ranitidine-induced Thrombocytopenia in a Neonate - A Case Report and Review of Literature. J Pediatr Pharmacol Ther 2019 Jan;24(1):66-71 [FREE Full text] [doi: 10.5863/1551-6776-24.1.66] [Medline: $\underline{30837818}$ ]

47. Dipyridamole [Persantine]: Prescribing Information. Boehringer Ingelheim International GmbH. 2019. URL: https://www. accessdata.fda.gov/drugsatfda docs/label/2019/012836s061lbl.pdf [accessed 2020-03-31]

48. Aspirin/Extended-Release Dipyridamole [Aggrenox]: Highlights of prescribing information Internet. Boehringer Ingelheim International GmbH. 2019 Dec. URL: https://docs.boehringer-ingelheim.com/Prescribing\%20Information/PIs/ Aggrenox\%20Caps/Aggrenox.pdf [accessed 2020-03-31]

49. Curantyl 25 (dipyridamole) prescribing information. Russian Drug Register. 2005. URL: https://pda.rlsnet.ru/ tn_index_id_3874.htm\#pokazaniya-preparata-kurantil- [accessed 2020-04-02]

50. Lette J, Tatus J, Fraser S, Miller D, Waters D, Heller G, et al. Safety of dipyridamole testing in 73,806 patients: The Multicenter Dipyridamole Safety Study. Journal of Nuclear Cardiology 1995 Jan;2(1):3-17. [doi:

10.1016/s1071-3581(05)80003-0]

51. Balakumar P, Nyo YH, Renushia R, Raaginey D, Oh AN, Varatharajan R, et al. Classical and pleiotropic actions of dipyridamole: Not enough light to illuminate the dark tunnel? Pharmacol Res 2014 Sep;87:144-150. [doi: 10.1016/j.phrs.2014.05.008] [Medline: 24861566]

52. Tonew M, Tonew E, Mentel R. The antiviral activity of dipyridamole. Acta Virol 1977 Mar;21(2):146-150. [Medline: 17283]

53. Tonew M, Dzeguze D. Dipyridamole, an inhibitor of mengovirus replication in FL and L cells. Chemotherapy 1977 Aug 5;23(3):149-158. [doi: 10.1159/000221983] [Medline: $\underline{189976}$ ]

54. Tenser RB, Gaydos A, Hay KA. Inhibition of Herpes Simplex Virus Reactivation by Dipyridamole. Antimicrob Agents Chemother 2001 Dec 01;45(12):3657-3659. [doi: 10.1128/aac.45.12.3657-3659.2001]

55. Patel SS, Szebeni J, Wahl LM, Weinstein JN. Differential inhibition of 2'-deoxycytidine salvage as a possible mechanism for potentiation of the anti-human immunodeficiency virus activity of 2',3'-dideoxycytidine by dipyridamole. Antimicrob Agents Chemother 1991 Jun 01;35(6):1250-1253 [FREE Full text] [doi: 10.1128/aac.35.6.1250] [Medline: 1656858]

56. Snoeck R, Andrei G, Balzarini J, Reymen D, De Clercq E. Dipyridamole Potentiates the Activity of Various Acyclic Nucleoside Phosphonates against Varicella-Zoster Virus, Herpes Simplex Virus and Human Cytomegalovirus. Antivir Chem Chemother 2016 Jun 23;5(5):312-321. [doi: 10.1177/095632029400500505]

57. Kuzmov K, Galabov AS, Radeva K, Kozhukharova M, Milanov K. [Epidemiological trial of the prophylactic effectiveness of the interferon inducer dipyridamole with respect to influenza and acute respiratory diseases]. Zh Mikrobiol Epidemiol Immunobiol 1985 Jun(6):26-30. [Medline: 3898670]

58. Fedorova GI, Slepushkin AN. [Epidemiologic and economic efficacy of massive prophylaxis of influenza and other acute respiratory viral infections using curantil in Moscow enterprises]. Ter Arkh 2002;74(11):18-21. [Medline: 12498118]

59. Guchev IA, Klochkov OI. [Dipyridamole prevention of outbreaks of respiratory infections in the homogeneous population]. Klin Med (Mosk) 2004;82(11):45-49. [Medline: 15656399]

60. Liu X, Li Z, Liu S, Sun J, Chen Z, Jiang M, et al. Potential therapeutic effects of dipyridamole in the severely ill patients with COVID-19. Acta Pharm Sin B 2020 Jul;10(7):1205-1215 [FREE Full text] [doi: 10.1016/j.apsb.2020.04.008] [Medline: $\underline{32318327]}$ 
61. Multicenter study for the treatment of Dipyridamole with novel coronavirus pneumonia (COVID-19) (ChiCTR2000030055 ). Chinese Clinical Trial Registry. 2020. URL: http://www.chictr.org.cn/showprojen.aspx?proj=49864 [accessed 2020-08-28]

62. Kim H, Liao JK. Translational therapeutics of dipyridamole. Arterioscler Thromb Vasc Biol 2008 Mar;28(3):s39-s42 [FREE Full text] [doi: 10.1161/ATVBAHA.107.160226] [Medline: 18174451]

63. Guo S, Stins M, Ning M, Lo EH. Amelioration of inflammation and cytotoxicity by dipyridamole in brain endothelial cells. Cerebrovasc Dis 2010 Aug;30(3):290-296 [FREE Full text] [doi: 10.1159/000319072] [Medline: 20664263]

64. Renvert S, Lindahl C, Roos-Jansåker AM, Lessem J. Short-term effects of an anti-inflammatory treatment on clinical parameters and serum levels of C-reactive protein and proinflammatory cytokines in subjects with periodontitis. J Periodontol 2009 Jun;80(6):892-900 [FREE Full text] [doi: 10.1902/jop.2009.080552] [Medline: 19485818]

65. Zimmermann GR, Avery W, Finelli AL, Farwell M, Fraser CC, Borisy AA. Selective amplification of glucocorticoid anti-inflammatory activity through synergistic multi-target action of a combination drug. Arthritis Res Ther 2009;11(1):R12 [FREE Full text] [doi: 10.1186/ar2602] [Medline: 19171052]

66. Macatangay B, Jackson E, Abebe K, Comer D, Cyktor J, Klamar-Blain C, et al. A Randomized, Placebo-Controlled, Pilot Clinical Trial of Dipyridamole to Decrease Human Immunodeficiency Virus-Associated Chronic Inflammation. J Infect Dis 2020 Apr 27;221(10):1598-1606. [doi: 10.1093/infdis/jiz344] [Medline: 31282542]

67. Granat F, Monzali C, Jeunesse E, Guerlin M, Trumel C, Geffré A, et al. Comparison of different anticoagulant associations on haemostasis and biochemical analyses in feline blood specimens. Journal of Feline Medicine and Surgery 2016 Jul 09;19(4):394-402. [doi: 10.1177/1098612x16628579]

68. Granat FA, Geffré A, Lucarelli LA, Braun JD, Trumel C, Bourgès-Abella NH. Evaluation of CTAD (citrate-theophylline-adenosine-dipyridamole) as a universal anticoagulant in dogs. J Vet Diagn Invest 2017 Sep 03;29(5):676-682. [doi: 10.1177/1040638717713793] [Medline: 28673194]

69. Yokota M, Tatsumi N, Tsuda I, Nishioka T, Takubo T. CTAD as a universal anticoagulant. J Autom Methods Manag Chem 2003;25(1):17-20 [FREE Full text] [doi: 10.1155/S1463924603000038] [Medline: 18924886]

70. Copeland H, Nolan P, Covington D, Gustafson M, Smith R, Copeland J. A method for anticoagulation of children on mechanical circulatory support. Artif Organs 2011 Nov;35(11):1018-1023. [doi: 10.1111/j.1525-1594.2011.01391.x] [Medline: 22097979]

71. Gomes OM, Gomes ES. Dipyridamole and low doses of heparin as a new successful physiopathologic and therapeutic approach in 2 cases of disseminated intravascular coagulation. Heart Surg Forum 2010 Feb 11;13(1):E49-E51. [doi: 10.1532/HSF98.20091134] [Medline: 20150041]

72. Asakura M, Asanuma H, Kim J, Liao Y, Nakamaru K, Fujita M, et al. Impact of adenosine receptor signaling and metabolism on pathophysiology in patients with chronic heart failure. Hypertens Res 2007 Sep;30(9):781-787. [doi: 10.1291/hypres.30.781] [Medline: 18037770 ]

73. Kitakaze M, Minamino T, Node K, Takashima S, Funaya H, Kuzuya T, et al. Adenosine and cardioprotection in the diseased heart. Jpn Circ J 1999 Apr;63(4):231-243 [FREE Full text] [doi: 10.1253/jcj.63.231] [Medline: 10475769]

74. Riksen N, Rongen G, Blom H, Boers G, Smits P. Reduced adenosine receptor stimulation as a pathogenic factor in hyperhomocysteinemia. Clin Chem Lab Med 2005;43(10):1001-1006. [doi: 10.1515/CCLM.2005.175] [Medline: 16197288]

75. Sanada S, Asanuma H, Koretsune Y, Watanabe K, Nanto S, Awata N, et al. Long-term oral administration of dipyridamole improves both cardiac and physical status in patients with mild to moderate chronic heart failure: a prospective open-randomized study. Hypertens Res 2007 Oct;30(10):913-919. [doi: 10.1291/hypres.30.913] [Medline: 18049022]

76. Kuo K, Hung S, Tseng W, Liu J, Lin M, Hsu C, et al. Dipyridamole decreases dialysis risk and improves survival in patients with pre-dialysis advanced chronic kidney disease. Oncotarget 2018 Jan 12;9(4):5368-5377 [FREE Full text] [doi: 10.18632/oncotarget.19850] [Medline: 29435184]

77. Hung C, Yang M, Lin M, Lin HY, Lim L, Kuo H, et al. Dipyridamole treatment is associated with improved renal outcome and patient survival in advanced chronic kidney disease. Kaohsiung J Med Sci 2014 Dec;30(12):599-607 [FREE Full text] [doi: 10.1016/j.kjms.2014.10.002] [Medline: 25476097]

78. Lee G, Choong H, Chiang G, Woo K. Three-year randomized controlled trial of dipyridamole and low-dose warfarin in patients with IgA nephropathy and renal impairment Internet. Nephrology 1997;3(1):117-121. [doi: 10.1111/j.1440-1797.1997.tb00201.x]

79. Beaufils M, Uzan S, Donsimoni R, Colau JC. Prospective controlled study of early antiplatelet therapy in prevention of preeclampsia. Adv Nephrol Necker Hosp 1986;15:87-94. [Medline: $\underline{3082120}$ ]

80. Fenofibrate [Triglide]: Highlights of Prescribing Information. Shionogi, Inc. 2012. URL: https://www.accessdata.fda.gov/ drugsatfda_docs/label/2013/021350s013lbl.pdf [accessed 2020-03-31]

81. Balakumar P, Sambathkumar R, Mahadevan N, Muhsinah AB, Alsayari A, Venkateswaramurthy N, et al. Molecular targets of fenofibrate in the cardiovascular-renal axis: A unifying perspective of its pleiotropic benefits. Pharmacol Res 2019 Jun;144:132-141. [doi: 10.1016/j.phrs.2019.03.025] [Medline: 30970278 ]

82. Grammatikos G, Farnik H, Bon D, Böhlig A, Bader T, Berg T, et al. The impact of antihyperlipidemic drugs on the viral load of patients with chronic hepatitis C infection: a meta-analysis. J Viral Hepat 2014 Aug 18;21(8):533-541. [doi: 10.1111/jvh.12274] [Medline: 24943517] 
83. Tomizawa A, Hattori Y, Inoue T, Hattori S, Kasai K. Fenofibrate suppresses microvascular inflammation and apoptosis through adenosine monophosphate-activated protein kinase activation. Metabolism 2011 Apr;60(4):513-522. [doi: 10.1016/j.metabol.2010.04.020] [Medline: 20580385]

84. Usui-Ouchi A, Ouchi Y, Ebihara N. The peroxisome proliferator-activated receptor pan-agonist bezafibrate suppresses microvascular inflammatory responses of retinal endothelial cells and vascular endothelial growth factor production in retinal pigmented epithelial cells. Int Immunopharmacol 2017 Nov;52:70-76. [doi: 10.1016/j.intimp.2017.08.027] [Medline: 28866026]

85. Terasawa T, Aso Y, Omori K, Fukushima M, Momobayashi A, Inukai T. Bezafibrate, a peroxisome proliferator-activated receptor $\alpha$ agonist, decreases circulating CD14(+)CD16(+) monocytes in patients with type 2 diabetes. Transl Res 2015 Feb;165(2):336-345. [doi: 10.1016/j.trsl.2014.07.008] [Medline: 25134759]

86. Huang W, Yin W, Chen J, Huang P, Chen J, Lin S. Fenofibrate Reverses Dysfunction of EPCs Caused by Chronic Heart Failure. J Cardiovasc Transl Res 2020 Apr 7;13(2):158-170. [doi: 10.1007/s12265-019-09889-y] [Medline: 31701352]

87. Oidor-Chan VH, Hong E, Pérez-Severiano F, Montes S, Torres-Narváez JC, Del Valle-Mondragón L, et al. Fenofibrate plus Metformin Produces Cardioprotection in a Type 2 Diabetes and Acute Myocardial Infarction Model. PPAR Res 2016;2016:8237264-8237214 [FREE Full text] [doi: 10.1155/2016/8237264] [Medline: 27069466]

88. Jakob T, Nordmann A, Schandelmaier S, Ferreira-González I, Briel M. Fibrates for primary prevention of cardiovascular disease events. Cochrane Database Syst Rev 2016 Nov 16;11:CD009753 [FREE Full text] [doi:

10.1002/14651858.CD009753.pub2] [Medline: 27849333]

89. Wang D, Liu B, Tao W, Hao Z, Liu M. Fibrates for secondary prevention of cardiovascular disease and stroke. Cochrane Database Syst Rev 2015 Oct 25;10(10):CD009580 [FREE Full text] [doi: 10.1002/14651858.CD009580.pub2] [Medline: 26497361]

90. Jonkers IJAM, de Man FHAF, van Tilburg NH, van der Laarse A, Sandset PM, Smelt AHM, et al. Alterations in the extrinsic pathway in hypertriglyceridemia do not cause a 'procoagulant state': effects of bezafibrate therapy. Blood Coagul Fibrinolysis 2001 Dec;12(8):705-712. [doi: 10.1097/00001721-200112000-00013] [Medline: 11734672]

91. Ceska R, Sobra J, Kvasnicka J, Procházková R, Kvasilová M, Haas T. [The effect of micronized fenofibrate on lipid parameters and fibrinogen in heterozygous familial hypercholesterolemia and familial combined hyperlipidemia]. Cas Lek Cesk 1996 Jul 26;135(13):413-416. [Medline: 8925538]

92. Durrington P, Mackness M, Bhatnagar D, Julier K, Prais H, Arrol S, et al. Effects of two different fibric acid derivatives on lipoproteins, cholesteryl ester transfer, fibrinogen, plasminogen activator inhibitor and paraoxonase activity in type IIb hyperlipoproteinaemia. Atherosclerosis 1998 May;138(1):217-225. [doi: 10.1016/s0021-9150(98)00003-3]

93. Sahebkar A, Serban M, Mikhailidis DP, Toth PP, Muntner P, Ursoniu S, LipidBlood Pressure Meta-analysis Collaboration (LBPMC) Group. Head-to-head comparison of statins versus fibrates in reducing plasma fibrinogen concentrations: A systematic review and meta-analysis. Pharmacol Res 2016 Jan;103:236-252. [doi: 10.1016/j.phrs.2015.12.001] [Medline: 26657419]

94. Maison P, Mennen L, Sapinho D, Balkau B, Sigalas J, Chesnier M, et al. A pharmacoepidemiological assessment of the effect of statins and fibrates on fibrinogen concentration. Atherosclerosis 2002 Jan;160(1):155-160. [doi: 10.1016/s0021-9150(01)00552-4]

95. Madrid-Miller A, Moreno-Ruiz LA, Borrayo-Sánchez G, Almeida-Gutiérrez E, Martínez-Gómez DF, Jáuregui-Aguilar R. Ipact of bezafibrate treatment in patients with hyperfibrinogenemia and ST-elevation acute myocardial infarction: a randomized clinical trial. Cir Cir 2010;78(3):229-237. [Medline: 20642906]

96. Kilicarslan A, Yavuz B, Guven GS, Atalar E, Sahiner L, Beyazit Y, et al. Fenofibrate improves endothelial function and decreases thrombin-activatable fibrinolysis inhibitor concentration in metabolic syndrome. Blood Coagulation \& Fibrinolysis 2008;19(4):310-314. [doi: 10.1097/mbc.0b013e3283009c69]

97. Ueno H, Saitoh Y, Mizuta M, Shiiya T, Noma K, Mashiba S, et al. Fenofibrate ameliorates insulin resistance, hypertension and novel oxidative stress markers in patients with metabolic syndrome. Obes Res Clin Pract 2011 Oct;5(4):e267-e360. [doi: 10.1016/j.orcp.2011.03.012] [Medline: 24331137]

98. Sildenafil citrate [Viagra]: Highlights of Prescribing Information. Pfizer, Inc. 2017. URL: https://www.accessdata.fda.gov/ drugsatfda docs/label/2014/20895s039s042lbl.pdf [accessed 2020-04-10]

99. Sildenafil citrate [Revatio]: Highlights of Prescribing Information. Pfizer, Inc. 2014 Jan. URL: https://www. accessdata.fda.gov/drugsatfda docs/label/2014/021845s011,022473s004,0203109s002lbl.pdf [accessed 2020-03-31]

100. Kniotek M, Boguska A. Sildenafil Can Affect Innate and Adaptive Immune System in Both Experimental Animals and Patients. J Immunol Res 2017;2017:4541958-4541958 [FREE Full text] [doi: 10.1155/2017/4541958] [Medline: 28316997]

101. A Pilot Study of Sildenafil in COVID-19 (NCT04304313). ClinicalTrials.gov. 2020. URL: https://clinicaltrials.gov/ct2/ show/NCT04304313 [accessed 2020-08-28]

102. Santi D, Giannetta E, Isidori A, Vitale C, Aversa A, Simoni M. Therapy of endocrine disease. Effects of chronic use of phosphodiesterase inhibitors on endothelial markers in type 2 diabetes mellitus: a meta-analysis. Eur J Endocrinol 2015 Mar;172(3):R103-R114. [doi: 10.1530/eje-14-0700] 
103. Aversa A, Vitale C, Volterrani M, Fabbri A, Spera G, Fini M, et al. Chronic administration of Sildenafil improves markers of endothelial function in men with Type 2 diabetes. Diabet Med 2008 Jan;25(1):37-44. [doi: 10.1111/j.1464-5491.2007.02298.x] [Medline: $\underline{18199130]}$

104. Tzoumas N, Farrah TE, Dhaun N, Webb DJ. Established and emerging therapeutic uses of PDE type 5 inhibitors in cardiovascular disease. Br J Pharmacol 2019 Nov 12:e. [doi: 10.1111/bph.14920] [Medline: $\underline{31721165]}$

105. Mostafa T. Non-Sexual Implications of Phosphodiesterase Type 5 Inhibitors. Sexual Medicine Reviews 2017 Apr;5(2):170-199. [doi: 10.1016/j.sxmr.2016.02.004]

106. Hutchings DC, Anderson SG, Caldwell JL, Trafford AW. Phosphodiesterase-5 inhibitors and the heart: compound cardioprotection? Heart 2018 Aug 08;104(15):1244-1250 [FREE Full text] [doi: 10.1136/heartjnl-2017-312865] [Medline: 29519873]

107. Brown KE, Dhaun N, Goddard J, Webb DJ. Potential therapeutic role of phosphodiesterase type 5 inhibition in hypertension and chronic kidney disease. Hypertension 2014 Jan;63(1):5-11. [doi: 10.1161/HYPERTENSIONAHA.113.01774] [Medline: 24101666]

108. Anderson SG, Hutchings DC, Woodward M, Rahimi K, Rutter MK, Kirby M, et al. Phosphodiesterase type-5 inhibitor use in type 2 diabetes is associated with a reduction in all-cause mortality. Heart 2016 Nov 01;102(21):1750-1756 [FREE Full text] [doi: 10.1136/heartjnl-2015-309223] [Medline: 27465053]

109. Barnes H, Brown Z, Burns A, Williams T. Phosphodiesterase 5 inhibitors for pulmonary hypertension. Cochrane Database Syst Rev 2019 Jan 31;1:CD012621 [FREE Full text] [doi: 10.1002/14651858.CD012621.pub2] [Medline: $\underline{30701543}$ ]

110. Rochwerg B, Neupane B, Zhang Y, Garcia CC, Raghu G, Richeldi L, et al. Treatment of idiopathic pulmonary fibrosis: a network meta-analysis. BMC Med 2016 Feb 03;14(1):18 [FREE Full text] [doi: 10.1186/s12916-016-0558-x] [Medline: 26843176]

111. Ashworth AJ. Enhanced recovery from respiratory infection following treatment with a PDE-5 inhibitor: a single case study. Prim Care Respir J 2012 Mar 27;21(1):17-17 [FREE Full text] [doi: 10.4104/pcrj.2012.00016] [Medline: 22382866]

112. Webb DJ, Vachiery J, Hwang L, Maurey JO. Sildenafil improves renal function in patients with pulmonary arterial hypertension. Br J Clin Pharmacol 2015 Aug 19;80(2):235-241 [FREE Full text] [doi: 10.1111/bcp.12616] [Medline: 25727860]

113. Aggrenox To Treat Acute Covid-19 (NCT04410328). ClinicalTrials.gov. 2020. URL: https://clinicaltrials.gov/show/ NCT04410328 [accessed 2020-08-28]

114. Dipyridamole to Prevent Coronavirus Exacerbation of Respiratory Status (DICER) in COVID-19 (NCT04391179). ClinicalTrials.gov. 2020. URL: https://clinicaltrials.gov/show/NCT04391179 [accessed 2020-08-28]

115. Trial of Open Label Dipyridamole - In Hospitalized Patients With COVID-19 (NCT04424901). ClinicalTrials.gov. 2020. URL: https://clinicaltrials.gov/show/NCT04424901 [accessed 2020-08-28]

116. Hogan II RB, Hogan III RB, Cannon T, Rappai M, Studdard J, Paul D, et al. Dual-histamine receptor blockade with cetirizine - famotidine reduces pulmonary symptoms in COVID-19 patients. Pulm Pharmacol Ther 2020 Aug 29;63:101942 [FREE Full text] [doi: 10.1016/j.pupt.2020.101942] [Medline: 32871242]

117. Janowitz T, Gablenz E, Pattinson D, Wang TC, Conigliaro J, Tracey K, et al. Famotidine use and quantitative symptom tracking for COVID-19 in non-hospitalised patients: a case series. Gut 2020 Sep 04;69(9):1592-1597. [doi: 10.1136/gutjnl-2020-321852] [Medline: 32499303]

118. Tomera K, Kittah J. Famotidine with celecoxib adjuvant therapy on hospitalized COVID-19 patients: A case series. SSRN. 2020. URL: https://papers.ssrn.com/sol3/papers.cfm?abstract_id=3646583 [accessed 2020-09-15]

119. Freedberg DE, Conigliaro J, Wang TC, Tracey KJ, Callahan MV, Abrams JA, Famotidine Research Group. Famotidine Use Is Associated With Improved Clinical Outcomes in Hospitalized COVID-19 Patients: A Propensity Score Matched Retrospective Cohort Study. Gastroenterology 2020 May 22:e [FREE Full text] [doi: 10.1053/j.gastro.2020.05.053] [Medline: 32446698]

120. Malone R, Tisdall P, Fremont-Smith P, Liu Y, Huang X, White K, et al. COVID-19: Famotidine, Histamine, Mast Cells, and Mechanisms. Res Sq 2020 Jun 22:37 [FREE Full text] [doi: 10.21203/rs.3.rs-30934/v2] [Medline: 32702719]

121. Ehrlich A, Uhl S, Ioannidis K, Hofree M, tenOever B, Nahmias Y. The SARS-CoV-2 transcriptional metabolic signature in lung epithelium. SSRN. 2020. URL: https://papers.ssrn.com/abstract=3650499 [accessed 2020-08-30]

122. Isidori AM, Giannetta E, Pofi R, Venneri MA, Gianfrilli D, Campolo F, et al. Targeting the NO-cGMP-PDE5 pathway in COVID-19 infection. The DEDALO project. Andrology 2020 Jun 11:e [FREE Full text] [doi: 10.1111/andr.12837] [Medline: 32526061]

123. Sildenafil in COVID-19 (NCT04489446). ClinicalTrials.gov. 2020. URL: https://clinicaltrials.gov/show/NCT04489446 [accessed 2020-08-28]

\section{Abbreviations}

ARDS: acute respiratory distress syndrome

bid: twice daily

cAMP: cyclic adenosine monophosphate 
cGMP: cyclic guanine monophosphate

CKD: chronic kidney disease

CRP: C-reactive protein

CTAD: citrate-theophylline-adenosine-dipyridamole

DEDALO: silDEnafil administration in DiAbetic and dysmetaboLic patients with COVID-19

FDA: Food and Drug Administration

GERD: gastroesophageal reflux disease

$\mathbf{H}_{\mathbf{2}} \mathbf{R A}$ : histamine type-2 receptor antagonist

HSV: herpes simplex virus

NO: nitric oxide

PAH: pulmonary arterial hypertension

PDE: phosphodiesterase-5

qid: four times daily

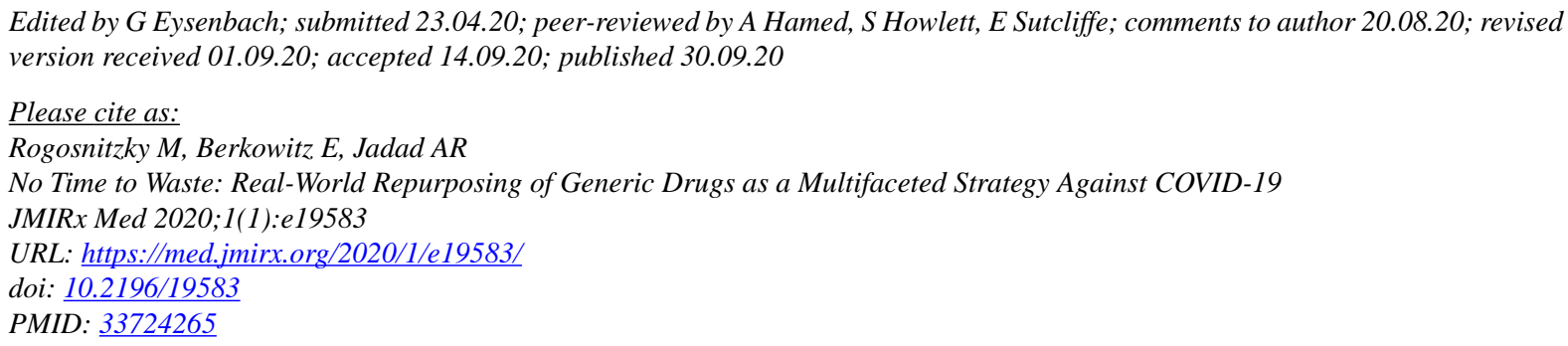

CMoshe Rogosnitzky, Esther Berkowitz, Alejandro R Jadad. Originally published in JMIRx Med (https://med.jmirx.org), 30.09.2020. This is an open-access article distributed under the terms of the Creative Commons Attribution License (https://creativecommons.org/licenses/by/4.0/), which permits unrestricted use, distribution, and reproduction in any medium, provided the original work, first published in the JMIRx Med, is properly cited. The complete bibliographic information, a link to the original publication on https://med.jmirx.org/, as well as this copyright and license information must be included. 